\title{
THE ATLANTIC SLAVE TRADE IN WORLD HISTORY
}

Jeremy Black

Routledge. 2015. pp. 173

ISBN: 9871138841338

\section{Reviewed by Erna Oliver}

Department of Christian Spirituality, Church History and Missiology University of South Africa, Pretoria

olivee@unisa.ac.za

Many books have been written on the subject of the slave trade. However, this book can be recommended as a good addition to these works mainly for the following reasons: Black starts by discussing the difficulty of providing definitions for the term slavery, which emphasises the fact that the book can be used as a general introduction to a very complex subject. He takes the current sentiments and opinions regarding this sensitive issue into account, reminding readers (and history students) about the need for caution when research leads from analyses to judgements. Sad but true are his concluding words: 'The curse of the past is not what happened but rather the inability to build on the past when looking at the present and to the future' (p. 162).

The book only focuses on the Atlantic slave trade (and not on the global phenomenon, although it does refer to the bigger picture) and emphasises the development of Western civilisation that went hand in hand with and was greatly built upon the slave trade. In line with the Themes in World History series goals, the book links the historic event with later developments in world history such as the impact of the slave trade on the colonies and Africa, as well as the persistence of the practice of slavery in the twentieth century. Jeremy Black is Professor of History at the University of Exeter in England. He is a seasoned writer with more than 100 publications to his name and his vast knowledge of the subject as well as his lively and interesting style of narration contribute to the positive experience of reading this book. I am impressed by the detailed bibliographies at the end of each chapter as well as the further reading list at the back that focuses on recent works in English. This list also contains references to two online bibliographical databases on the subject.

\section{UNISA $\cong$}


The book is recommended to people who want to get a general overview of the origin, influence of and lingering consequences of the Atlantic slave trade. As a scholarly work, it could serve as an introduction to this topic as well as an example of how context is influencing historical methodology. 